\title{
Dendritic Cells Generated From Patients With Androgen-Independent Prostate Cancer Are Not Impaired in Migration and T-Cell Stimulation
}

\author{
Ying Waeckerle-Men, ${ }^{1,2}$ Edith Uetz-von Allmen, ${ }^{1}$ Roger von Moos, ${ }^{3}$ \\ Brendan J. Classon, ${ }^{4}$ Elke Scandella, ${ }^{1}$ Hans-Peter Schmid, ${ }^{5}$ Burkhard Ludewig, ${ }^{1}$ \\ Marcus Groettrup, ${ }^{1,2,6}$ and Silke Gillessen ${ }^{3 *}$ \\ 'Research Department, Cantonal Hospital St. Gallen, St. Gallen, Switzerland \\ ${ }^{2}$ Biotechnology Institute Thurgau, Tägerwilen, Switzerland \\ ${ }^{3}$ Oncology Department, Cantonal Hospital St. Gallen, St. Gallen, Switzerland \\ ${ }^{4}$ Avidex Ltd., Milton Park, Abingdon, United Kingdom \\ ${ }^{5}$ Urology Department, Cantonal Hospital St. Gallen, St. Gallen, Switzerland \\ ${ }^{6}$ Department of Biology, Division of Immunology, University of Constance, Konstanz, Germany
}

\begin{abstract}
BACKGROUND. Dendritic cell (DC)-based vaccination has been investigated as immunotherapy for several types of cancer. A potential drawback to vaccination with autologous monocyte-derived DCs (MoDCs) could be that MoDCs from patients are functionally impaired. In case of androgen-independent prostate cancer (CaP), the cancer itself, diverse prior therapies, and the hormone manipulation may affect the immune system.

METHODS. MoDCs from patients suffering from androgen-independent $\mathrm{CaP}$ were generated according to a clinically applicable protocol to evaluate the phenotype, maturation capacity, migration, and T-cell stimulation of these cells compared with those generated from tumor-free donors.

RESULTS. MoDCs generated from CaP patients could be fully matured and efficiently migrated towards the chemokine CCL21. They had a strong potency to activate allogeneic CD4 ${ }^{+}$ and CD8 ${ }^{+}$T-cells and to present antigens to specific CTL.

CONCLUSIONS. Our data suggest that MoDCs from patients with androgen-independent $\mathrm{CaP}$ are functionally intact and hence qualify as cellular vaccines for immunotherapy of advanced stage $\mathrm{CaP}$.
\end{abstract}

KEY WORDS: prostate cancer; cancer vaccine; monocyte-derived dendritic cells (MoDCs); DC phenotype and functions 


\section{INTRODUCTION}

Dendritic cell (DC)-based immunotherapy is emerging as a modality for treatment of solid and hematologic neoplasia [1]. DCs are professional antigenpresenting cells of the immune system with the capacity to stimulate or inhibit immune responses [2]. They are able to take up and process antigens and to migrate to the draining lymph nodes, where they present antigen to T-lymphocytes. Whereas immature DCs are very efficient at antigen uptake, they have to be matured to elicit productive T-cell responses [3]. The matured DCs express high levels of major histocompatibility complex (MHC) and costimulatory molecules. They play a major role in induction of primary T-cell dependent immune responses [4] and are considered to be the most potent adjuvant for generation of antitumor immunity [5].

Although DCs are rare cells in the circulating blood, they can be generated in reasonable numbers from monocytes or $\mathrm{CD} 34^{+}$precursor cells by culture in granulocyte-macrophage colony-stimulating factor (GM-CSF) and interleukin-4 (IL-4) [6,7]. For maturation, they can be incubated with different stimuli, such as LPS, CD40L, poly I:C, or proinflammatory cytokines. Recently, we have shown that addition of Prostaglandin E2 (PGE2) to the maturing DCs is crucial for effective migration of the matured DCs $[8,9]$.

Patients with androgen-independent prostate cancer $(\mathrm{CaP})$ have often had diverse therapies which may affect their immune system in addition to potential weakening of the immune system by the cancer itself. Moreover, the function of DCs or T-cells may be affected by androgen ablation in these patients.

It has been shown that immature DCs from patients with $\mathrm{CaP}$ can be generated and are active in presenting tetanus toxoid to autologous T-cells [10]. Several clinical studies with DC-based immunotherapy in patients with $\mathrm{CaP}$ have been published and have demonstrated some efficacy [11-14]. But data regarding the characterization of monocyte-derived DCs (MoDCs) generated from blood of patients with androgen-independent $\mathrm{CaP}$ are sparse and not much is known about the ability of patients to generate effective $\mathrm{CD}^{+}$and $\mathrm{CD} 8^{+} \mathrm{T}$-cell responses in vitro. In particular, the migration of MoDCs from CaP patients towards the chemokines CCL19 and CCL21, which direct matured DCs from a peripheral site of infection into the T-cell areas of draining lymph nodes and the spleen [15], has not been assessed, nor has the cell surface expression of the chemokine receptor CCR7 on such MoDCs been determined. In this study, we examined the quality, the migration capacity, and the capacity to stimulate allogenic T-cells of MoDCs from patients with androgen-independent $\mathrm{CaP}$ after maturation in comparison to MoDCs from tumor-free blood donors. In addition, we also tested the stimulation of antigen specific $\mathrm{T}$-cells from $\mathrm{CaP}$ patients by the respective autologous MoDCs in vitro. We show here that MoDCs and T-cells from CaP patients can be functionally intact, which is an important parameter for the conductance of DC-based immunotherapy of androgen-independent $\mathrm{CaP}$.

\section{PATIENTS, MATERIALS AND METHODS}

\section{Patients}

The patients are participants in a trial of vaccination with antigen loaded MoDCs for androgenindependent CaP (Table I). This trial is conducted in the Cantonal Hospital St. Gallen and ongoing. It is approved by the Regional Ethical Committee.

\section{Cell Culture Reagents and Materials}

AIM- $V^{\circledR}$ medium was purchased from Invitrogen (Groningen, the Netherlands). RPMI and IMDM cell culture media were obtained either from Invitrogen (Groningen, the Netherlands) or from Sigma (Taufkirchen, Germany). Human $\mathrm{AB}$ serum was bought from Cambrex Bio Science (Walkersville, MD). Ficoll-Paque ${ }^{\circledR}$ was obtained from Pharmacia (Uppsala, Sweden). GMP human recombinant cytokines IL-4, TNF- $\alpha$, IL-1 $\beta$, and IL- 6 were purchased from

\section{TABLE I. Patients Characteristics}

\begin{tabular}{lclll}
\hline Patient & $\begin{array}{c}\text { Age at diagnosis, } \\
\text { years }\end{array}$ & \multicolumn{1}{c}{ Metastases } & $\begin{array}{c}\text { Years since } \\
\text { diagnosis }\end{array}$ & \multicolumn{1}{c}{ Prior treatments } \\
\hline P04 & 72 & Bone, lymphnodes & 5 & $\begin{array}{l}\text { Pelvic lymphadenectomy, external radiotherapy, } \\
\text { LHRH analog, antiandrogen, estramustine }\end{array}$ \\
P07 & 58 & Bone, lymphnodes & 1 & $\begin{array}{l}\text { Pelvic lymphadenectomy, LHRH analog, PC-SPES } \\
\text { Orchiectomy, external radiotherapy }\end{array}$ \\
P09 & 73 & Bone, lymphnodes & 6 & $\begin{array}{l}\text { Orchiectomy, antiandrogen, external radiotherapy } \\
\text { P12 }\end{array}$ \\
P16 & 73 & Bone & 5 & LHRH analog, treatment with samarium \\
\hline
\end{tabular}

LHRH, luteinizing hormone-releasing hormone. 
CellGenix (Freiburg, Germany). Recombinant human GM-CSF (Leukine ${ }^{\mathbb{R}}$ Sargramostim) was obtained from Immunex ${ }^{\circledR}$ (Seattle, WA). Prostaglandin E2 (Prostin E2) was obtained from Pharmacia \& Upjohn (Dübendorf, Switzerland). Human chemokines CCL19 and CCL21 were bought from R\&D Systems (WiesbadenNordenstadt, Germany).

\section{Generation of MoDCs}

MoDCs were generated from human peripheral blood mononuclear cells (PBMC) as previously described [8,9]. In brief, 30-50 $\mathrm{ml}$ of heparinized blood were obtained from $\mathrm{CaP}$ patients or tumor-free donors to obtain PBMC with density gradient centrifugation on Ficoll-Paque ${ }^{\circledR}$ at $1,800 \mathrm{rpm}$ for $20 \mathrm{~min}$, then washed three times with PBS. PBMC were resuspended in AIM$\mathrm{V}$ medium as $4-6 \times 10^{6}$ cells $/ \mathrm{ml}$ and were seeded to $25 \mathrm{~cm}^{2}$ tissue culture flasks (TPP, Switzerland) for $2 \mathrm{hr}$ at $37^{\circ} \mathrm{C}$ to allow monocytes to adhere to the plastic surface. Non-adherent cells were removed by three times washing with PBS. Tightly adhered monocytes were further cultured in $5 \mathrm{ml}$ of DC-medium (AIM-V containing $1,000 \mathrm{U} / \mathrm{ml}$ of GM-CSF and $800 \mathrm{U} / \mathrm{ml}$ of IL-4). On day 3, the same volume of fresh DC-medium was added to the cell culture. On day 5, immature MoDCs were further stimulated with a cocktail of proinflammatory cytokines (fresh DC-medium supplemented with $20 \mathrm{ng} / \mathrm{ml}$ of TNF- $\alpha, 10 \mathrm{ng} / \mathrm{ml}$ of IL-1 $\beta$, $1,000 \mathrm{U} / \mathrm{ml}$ of IL- 6 , and $1 \mu \mathrm{g} / \mathrm{ml}$ of PGE2) for another $48 \mathrm{hr}$. The purity of MoDCs obtained under this experimental condition was about $90 \%$ by flow cytometric analysis (data not shown). To freeze MoDCs, cells were resuspended in cold AIM V medium as 1$2 \times 10^{7}$ cells $/ \mathrm{ml}$. The same volume of cold two times freezing medium (consisting of $80 \%$ autologous serum and 20\% DMSO) was then carefully added to MoDCs. One milliliter of cell suspension was immediately transferred to $1.8 \mathrm{ml}$ CryoTube ${ }^{\mathrm{TM}}$ vials (Nalge Nunc International, Rochester, NY) to be cryopreserved at $-80^{\circ} \mathrm{C}$ in NALGENE Cryo $1^{\circ} \mathrm{C}$ Freezing Container (Nalge Nunc) until the further use. For thawing MoDCs, CryoTube vials were warmed in waterbath at $37^{\circ} \mathrm{C}$. After MoDCs were defrosted, the cell suspension was immediately washed with cold PBS for three times. MoDCs were then resuspended in AIM V medium for further studies.

\section{Phenotypic Analysis of MoDCs}

The phenotype of immature MoDCs or MoDCs matured with inflammatory cytokines was analyzed on a FACScan ${ }^{\circledR}$ flow cytometer (Becton Dickinson) after staining with following $\mathrm{mAbs}$ according to the manufacturer's protocols: FITC-labeled anti-human CD14, CD16, CD19, CD40, CD80, CD83, CD86, HLA-DR (obtained from Immunotech, Berlin, Germany or Pharmingen, Basel, Switzerland). The respective isotype controls were FITC-labeled mouse IgG1, IgG2a, or IgG2b. Matured MoDCs were also stained with $\mathrm{mAb}$ rat anti-human CCR7 (clone 3D12, a kind gift from Prof. Dr. R. Förster, Institute of Immunology, Hannover Medical School, Germany). FITC-conjugated goat-antirat IgG (Jackson Immunoresearch, La Roche, Switzerland) was used as secondary antibody for anti-CCR7 staining.

\section{In Vitro Chemotaxis Assay for CCR7-Triggered DC MigrationTowards CCL2I}

The capacity of matured MoDCs to migrate in a CCR7-dependent manner was measured by an in vitro chemotaxis assay as previously described [8]. Briefly, $600 \mu \mathrm{l}$ of DC-medium containing $250 \mathrm{ng} / \mathrm{ml}$ CCL21 or DC-medium without chemokine (spontaneous migration control) were added to the bottom chamber of 24-well Transwell ${ }^{\circledR}$ plates with polycarbonate filters of $5-\mu \mathrm{m}$ pore size (Corning Costar, Cambridge, MA). MoDCs were resuspended at $1 \times 10^{6} / \mathrm{ml}$ in DCmedium and $100 \mu \mathrm{l}$ of cells were added to the upper chamber. The plates were incubated for $3 \mathrm{hr}$ at $37^{\circ} \mathrm{C}$. After careful removal of the upper chamber, $500 \mu \mathrm{l}$ of cells (migrated cells) in the bottom chamber was collected and counted for $45 \mathrm{sec}$ with flow cytometry using CellQuest software (Becton Dickinson). Each experiment was performed in duplicates. The percentage of migrated cells was calculated as following: \% migrated DCs $=$ (number of migrated DCs/number of total DCs) $\times 100 \%$. Values were given as the mean percentage of migrated cells \pm SEM.

\section{Mixed Lymphocyte Reaction (MLR)}

$\mathrm{CD}^{+}$and $\mathrm{CD} 8^{+}$T-cells were purified from PBMC of healthy donors by positive selection on anti-CD4 or anti-CD8 MicroBeads (Miltenyi, Bergisch Gladbach, Germany) and resuspended in R-10 medium (RPMI medium containing 10\% AB serum). The indicated numbers of MoDCs were co-cultured with allogeneic $\mathrm{CD}^{+}\left(1 \times 10^{5} /\right.$ well $)$ or CD8 ${ }^{+}$T-cells $\left(2 \times 10^{5} /\right.$ well $)$ in 96-well flat bottom cell culture plates in duplicates. On day $3,{ }^{3} \mathrm{H}$-thymidine $(1 \mu \mathrm{Ci} /$ well $)$ was added and the incorporation was determined after 16-18 hr.

\section{In Vitro Restimulation of Antigen Specific CD8 T-Cells With MoDCs}

MoDCs of HLA-A*0201 positive CaP patients were pulsed with $5 \mu \mathrm{g} / \mathrm{ml}$ of peptides FluM ${ }_{58-66}$ (HLA$\mathrm{A}^{*} 0201$ restricted peptides from influenza $\mathrm{A}$ virus matrix protein 1, amino acid sequence 58-66) or PSCA $_{14-22}$ (prostate stem cell antigen, amino acid 
sequence $14-22)$ for $2 \mathrm{hr}$ at $37^{\circ} \mathrm{C}$, respectively. After washing, $1 \times 10^{6} \mathrm{MoDC}$ sere used to activate $5 \times 10^{6}$ autologous PBMC in 24-well plates in $2 \mathrm{ml}$ of D-10 medium (DMEM medium supplemented with $1 \%$ HEPES and $10 \%$ AB serum). Cells were cultured for 7 days at $37^{\circ} \mathrm{C}$ with $5.5 \% \mathrm{CO}_{2}$.

\section{Detection of Antigen Specific CD8 ${ }^{+}$T-Cells by MHC Class I Peptide Multimer Staining}

Fresh PBMC obtained from HLA-A*0201 CaP patients were stained with $\operatorname{Pro}^{\mathrm{TM}}$ Flu-pentamer-PE F2B-G specific to FluM ${ }_{58-66}$ (Proimmune Ltd., Oxford, UK) or with PSCA-tetramer-PE specific to PSCA PA-22 $_{14}$ (Avidex Ltd., Abingdon, UK), respectively, and costained with FITC-labeled anti-human CD8 mAb (Immunotech, Berlin, Germany) for flow cytometry. Alternatively, PBMC were restimulated with FluM ${ }_{58-66}$ or PSCA $\mathrm{A}_{14-22}$ for one cycle and then were stained with the respective multimers for flow cytometric analysis. The percentage of relevant antigen specific $\mathrm{CD}^{+} \mathrm{T}$ cells out of whole $\mathrm{CD}^{+}$cells were analyzed in the pregated lymphocyte population by using CellQuest software.

\section{RESULTS}

\section{Phenotype of MoDCs Prepared From CaP Patients}

One of our major goals is to establish and optimize DC-based vaccination against androgen-independent prostate carcinoma. For this purpose, we needed to know whether it would be possible to generate DCs from monocytes of $\mathrm{CaP}$ patients who have received androgen-ablation treatment and diverse other treatments. Therefore, we collected a small amount of blood from the enrolled $\mathrm{CaP}$ patients to perform a series of tests, in terms of HLA allele specificity (especially HLA-A*0201, for peptide-based DC vaccination), T-cell function, and generation of MoDCs under serum-free cell culture conditions for clinical use. As shown in Figure 1A, after 5 days of differentiation of monocytes in the presence of GM-CSF and IL-4, the surface markers of the cultured cells became CD14 ${ }^{-}, \mathrm{CD}_{16}{ }^{-}$, $\mathrm{CD}^{-}{ }^{-}, \mathrm{CD}_{40}^{+}, \mathrm{CD}^{\mathrm{low}}, \mathrm{CD}^{-} 3^{-}, \mathrm{CD}^{+} 6^{+}, \mathrm{HLA}^{-} \mathrm{DR}^{+}$ (MHC class II molecules), and $\mathrm{CCR}^{-}$, a typical phenotype of immature DCs. After stimulating these immature MoDCs with proinflammatory cytokines IL$1 \beta$, IL-6, TNF- $\alpha$, and PGE2 for another $48 \mathrm{hr}$, upregulation of CD80, CD83, CD86, HLA-DR, and CCR7 were observed indicating the maturation of MoDCs (Fig. 1B). Furthermore, matured MoDCs can be cryopreserved at $-80^{\circ} \mathrm{C}$ as described in Materials and Methods without any change of the phenotype (Fig. 1C). In addition, no significant difference in the cell surface expression of CD83 and CCR7 (Fig. 2) as well as other MoDC maturation markers was observed between the tested $\mathrm{CaP}$ patients and tumor-free donors under our experimental conditions.

\section{MoDC Migration Capacity of CaP Patients}

A great concern of MoDCs generated in vitro for DCbased immunotherapy is that these DCs should keep the mobile capacity in order to be able to migrate from the site of injection to T-cell zones of secondary lymphoid organs to present the acquired antigens for the activation of specific T-cells. All of our matured MoDCs expressed high level of CCR7 (Fig. 2B), the key chemokine receptor for DC migration towards CCL21 and CCL19 [15], suggesting their mobile capacity. These MoDCs indeed were able to migrate very efficiently towards CCL21 and CCL19 (Fig. 3 and data not shown) in an in vitro chemotaxis assay, indicating that the migratory capacity of MoDCs of the tested CaP patients was not impaired.

\section{In Vitro Stimulation of Allogeneic T-Lymphocytes by MoDCs}

We next examined the capacity of MoDCs of CaP patients to stimulate allogeneic T-cells in mixed $\mathrm{T}$ lymphocyte reactions in vitro, and compared it with MoDCs generated from tumor-free donors. As shown in Figure 4, similar levels of T-cell proliferation were observed when matured MoDCs of CaP patients or of tumor-free donors were co-cultured with $\mathrm{CD}^{+}$and $\mathrm{CD}^{+}$allogeneic T-cells, indicating the normal T-cell activation function of these MoDCs.

\section{Stimulation of Antigen Specific CD8 T-Cells With MoDCs of CaP Patients}

We further assessed the potential of MoDCs of CaP patients for activating antigen specific CTL. For this purpose, PBMC of HLA-A*0201 positive CaP patients were stimulated in vitro with MoDCs pulsed with two HLA-A*0201 restricted epitopes, Flu $58-66$ (derived from influenza virus matrix protein 58-66) and PSCA $_{14-22}$ (derived from prostate stem cell antigen 14-22), respectively. The quantities of peptide specific CTL were determined by MHC class I peptide multimer staining and flow cytometry. As shown in Figure 5, after one cycle of peptide-specific restimulation, higher Flu CTL responses were observed in four of five CaP patients in vitro (Fig. 5A). Stronger PSCA CTL responses were detected in all five tested $\mathrm{CaP}$ patients after restimulation (Fig. 5B). Taking together, these data indicated the strong capacity of antigen presentation of MoDCs and the feasibility to activate viral or tumor antigen specific CTL of CaP patients. 


\section{A. immature MoDC}

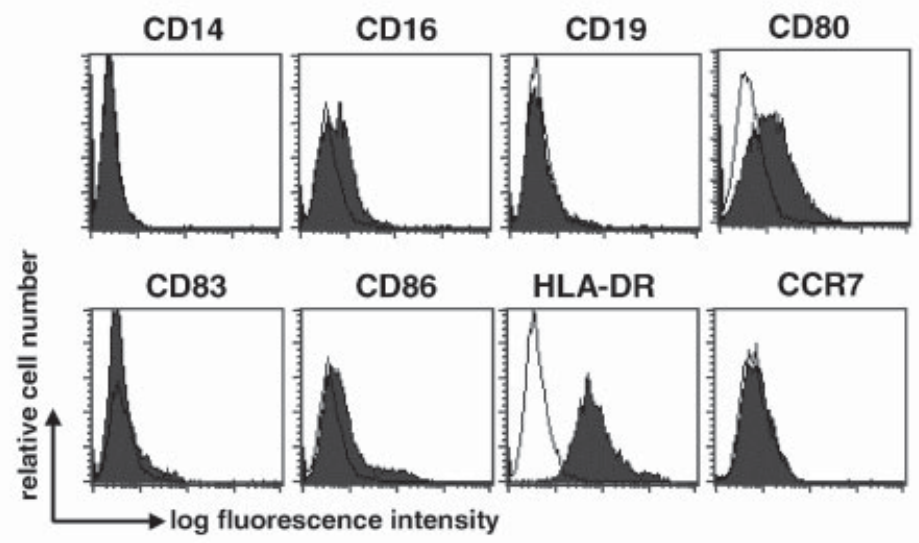

\section{B. fresh matured MoDC}

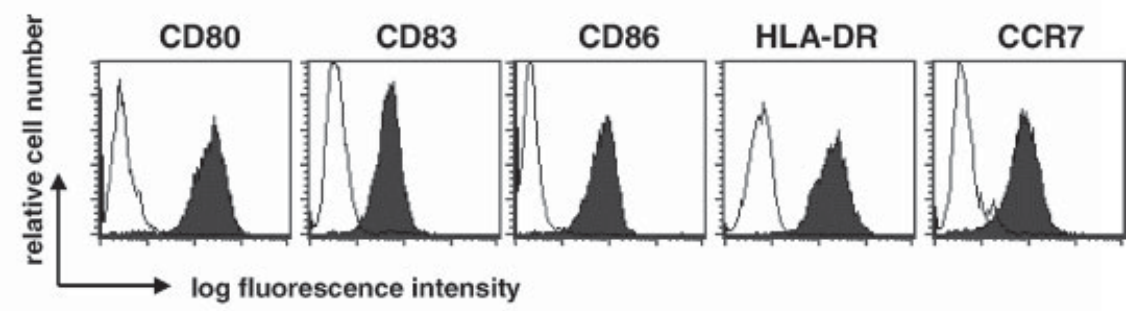

\section{C. cryopreserved MoDC}

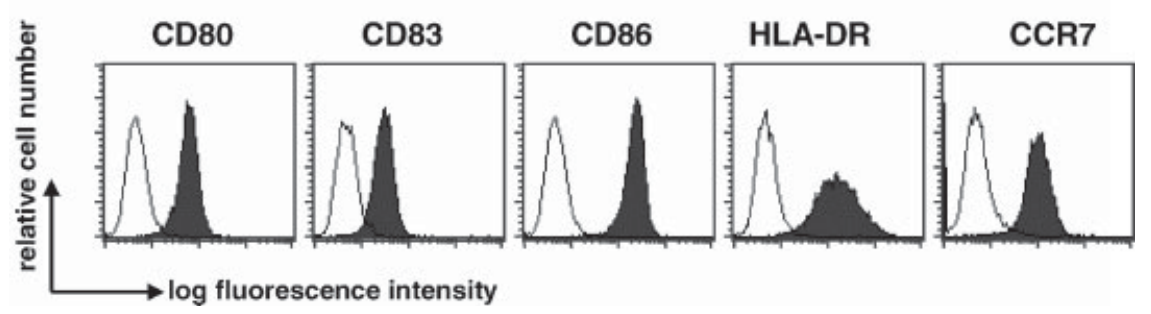

Fig. I. Phenotype of MoDCs generated from CaP patients. MoDCs were prepared from PBMC of CaP patients as described in Materials and Methods. Immature MoDCs (A), MoDCs activated with proinflammatory cytokinesTNF- $\alpha$, IL-I $\beta$, IL- 6 , and PGE2 for $48 \mathrm{hr}$ (B) and $-80^{\circ} \mathrm{C}$ cryopreserved/thawed matured MoDCs (C) were stained with the indicated mAbs for phenotypic analysis with flow cy tometry (shown as filled black histograms), respectively. Open line histograms represent staining with isotype matched control mAbs. Data of one CaP patient (PI2) are shown, who is representative for MoDCs generated from all tested CaP patients.

\section{DISCUSSION}

For a successful DC-vaccination strategy in patients with androgen-independent $\mathrm{CaP}$, it is essential that the generation and quality of the DCs generated are sufficient to elicit an immune response. Additionally, it is necessary that antigen-specific T-cells of patients with androgen-independent $\mathrm{CaP}$ can be stimulated with a vigor that is comparable to healthy individuals despite hormonal manipulation and other potentially immunocompromising therapies like radiotherapy or chemotherapy. Our study shows that MoDCs from patients with androgen-independent $\mathrm{CaP}$ can be generated in sufficient quantities in human blood as has been shown by others [10-12,14]. The surface markers of the immature DCs of the patients with androgenindependent $\mathrm{CaP}$ are indistinguishable from the DCs of blood donors.

Since inactivated DCs may cause T-cell tolerance instead of effective T-cell immunity [3,16], the proper activation of DCs is crucial. After considering several alternative DC maturation strategies, for example, TLR ligands or CD40, we decided to employ a proinflammatory cytokine cocktail for DC maturation consisting 


\section{A. $\mathrm{CD83}$}

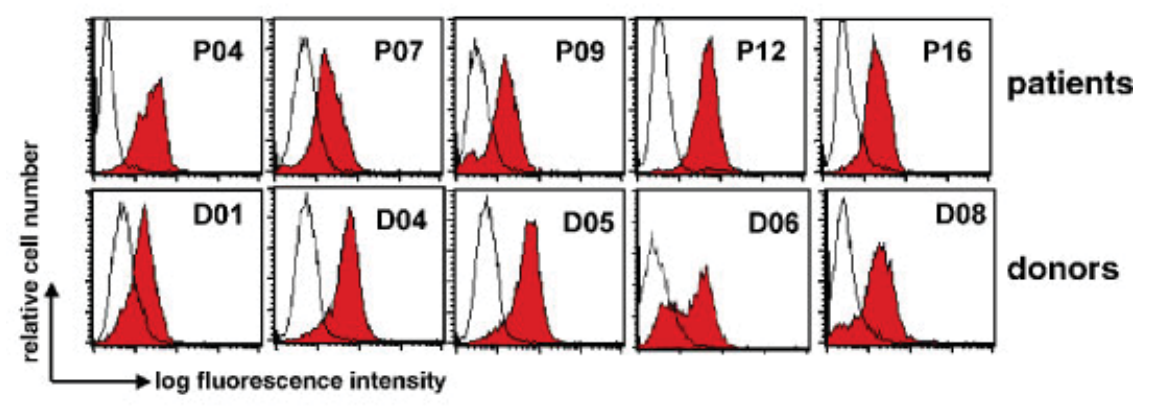

\section{B. CCR7}

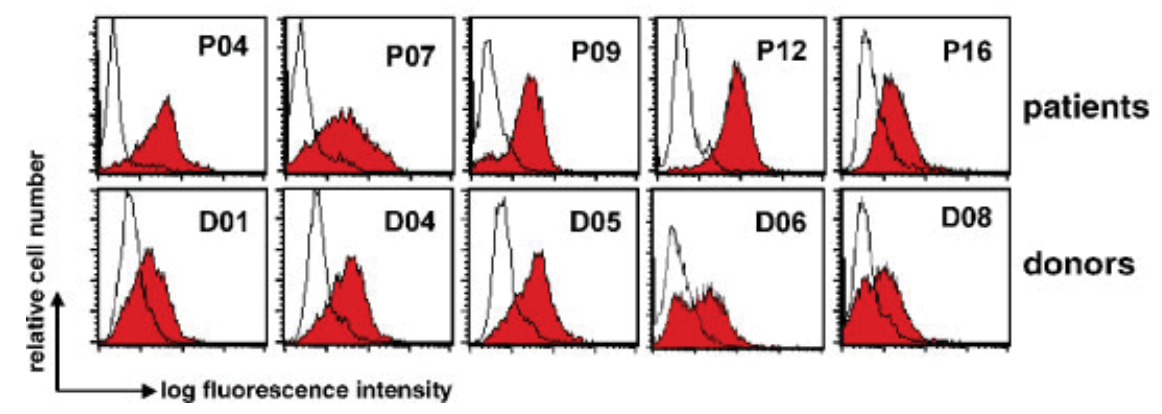

Fig. 2. Comparison of CD83 and CCR7 expression of matured MoDCs obtained from CaP patients and tumor-free donors. MoDCs matured with proinflammatory cytokines were prepared from the indicated $\mathrm{CaP}$ patients and tumor-free donors and were stained with $\mathrm{mAbs}$ to $\mathrm{CD} 83$ (A) and CCR7 (B) and analyzed with flow cytometry (shown as filled black histograms). Open line histograms represent staining with isotypematched control mAbs. [Color figure can be viewed in the online issue, which is available at www.interscience. wiley.com.]

of TNF- $\alpha$, IL-1 $\beta$, IL-6, and PGE2 [17]. In particular, PGE2 has been shown to be essential to achieve migration of DCs $[8,18]$. After incubation with this proinflammatory cytokine cocktail, the DCs of $\mathrm{CaP}$

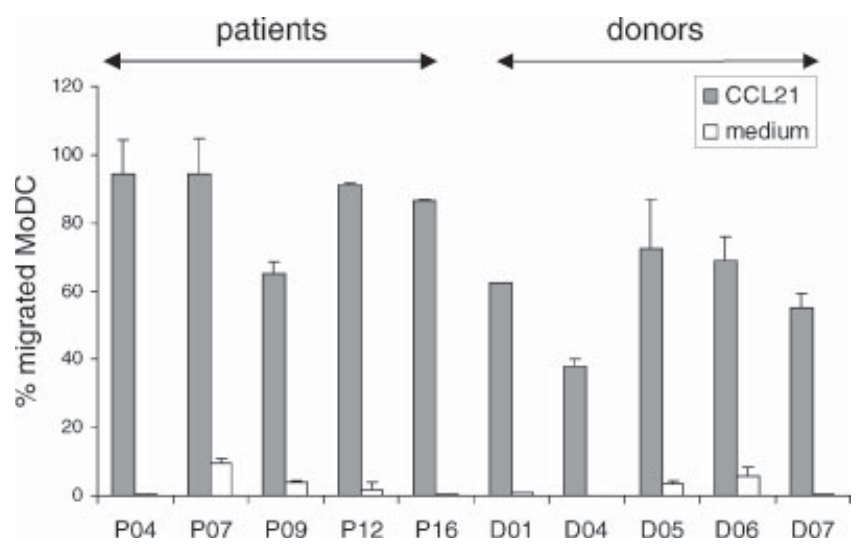

Fig. 3. In vitro migration capacity of MoDCs of $\mathrm{CaP}$ patients and donors. MoDCs matured with proinflammatory cytokines were generated from CaP patients (POI to P25) or from tumor-free donors (D0I to D07) and subsequently tested for CCR7-triggered migration towards CCL2I with chemotaxis assay (gray bars). Medium without CCL2I was used as control for spontaneous cell migration (opened bars). The percentage of migrated MoDCs was calculated as the mean of duplicate measurements \pm SEM. patients showed a full maturation comparable to that of tumor-free blood donors as indicated by similar upregulation of CD80, CD83, CD86, HLA-DR, and CCR7 (Figs. 1 and 2).

Since DCs are usually therapeutically administered either intradermally or subcutaneously, a key factor determining their efficacy is their ability to migrate to draining lymph nodes. Since it has been reported that as few as 5\% of intradermally administered matured DCs reach the draining lymph nodes [19], we wished to verify the in vitro migratory properties of MoDCs. In our study, we show that at least in vitro the capacity to migrate of DCs from patients with $\mathrm{CaP}$ is not impaired when compared to DCs of tumor free individuals (Fig. 3), a result which is consistent with their CCR7 ${ }^{+}$ phenotype (Fig. 2). To our knowledge, this is the first study, which investigates the migratory capacity of MoDCs from CaP patients.

In the current trials of DC-vaccination for tumors, the focus is mainly on induction of cytotoxic $\mathrm{CD}^{+}$ $\mathrm{T}$-cells. In some instances, recruitment of non-specific $\mathrm{CD}^{+}$T-cell help has been achieved through coadministration of keyhole limpet hemocyanin (KLH) but for optimal results, $\mathrm{CD}^{+} \mathrm{T}$-cell help should ideally be tumor specific [20]. In our MLR experiments, it has been shown that the MoDCs of the 


\section{A. CD4+ $\mathrm{T}$ cells}
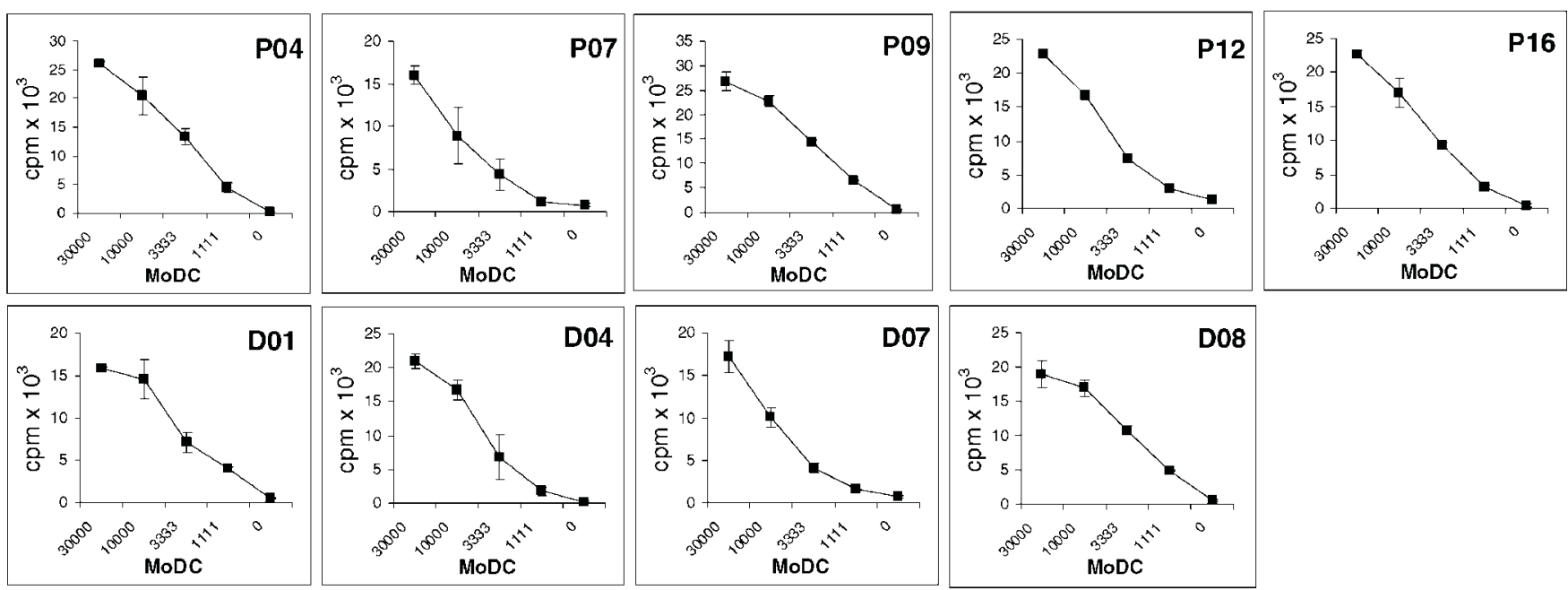

\section{B. CD8+ T cells}
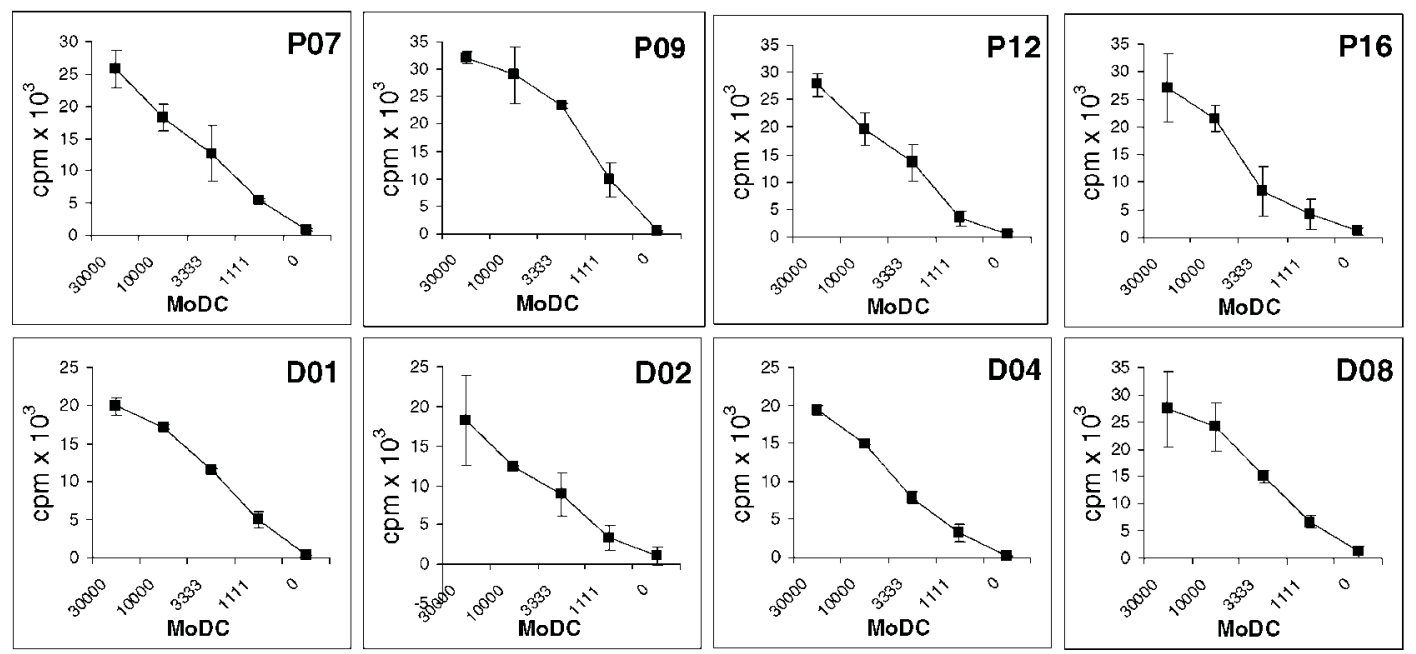

Fig. 4. Allogeneic stimulatory capacity of MoDCs from CaP patients and tumor-free donors by mixed lymphocyte reaction (MLR). Proinflammatory cytokine-matured MoDCs of CaP patients (POI-P25) or of tumor free donors (D0I-D08) were incubated with indicated numbers of magnetically purified allogeneic $\mathrm{CD}^{+}(\mathbf{A})$ or $\mathrm{CD}^{+} \mathrm{T}$-cells $(\mathbf{B})$. After 4 days of co-culture, T-cell proliferation was measured by ${ }^{3} \mathrm{H}$-thymidine incorporation. The data are shown as the mean of duplicate cultures from six independent experiments \pm SEM.

patients are as effective as MoDCs of tumor-free individuals to stimulate allogenic $\mathrm{CD}^{+}$and $\mathrm{CD}^{+}$ T-cells (Fig. 4). In addition, stimulation of antigen specific $\mathrm{CD}^{+}$T-cells as measured by MHC multimer staining showed that the majority of patients with androgen-independent $\mathrm{CaP}$ showed higher Flu specific CTL responses after restimulation with autologous DCs pulsed with an HLA-A*0201 restricted epitope of the influenza matrix protein Flu $\mathrm{u}_{58-66}$ (Fig. 5A). One of the patients had a very high number of Flu specific $\mathrm{CD}^{+}$T-cells before restimulation, which may have been the result of a current infection although in this case, the response was not further enhanced following in vitro restimulation. For PSCA specific $\mathrm{CD}^{+}$T-cells, there was an increase in all patients after one restimulation with antigen (Fig. 5B). This shows not only that the antigen-presenting capacity of MoDCs generated from patients with androgen-independent $\mathrm{CaP}$ is robust, but also that it is feasible to activate viral and tumoral antigen specific CTL in patients with androgen-independent CaP. We have not assayed for the presence of antigen-specific $\mathrm{CD}^{+} \mathrm{T}$-cells since no MHC class II binding peptides are used in our ongoing trial, but Schuler et al. have 


\section{A. Flu}
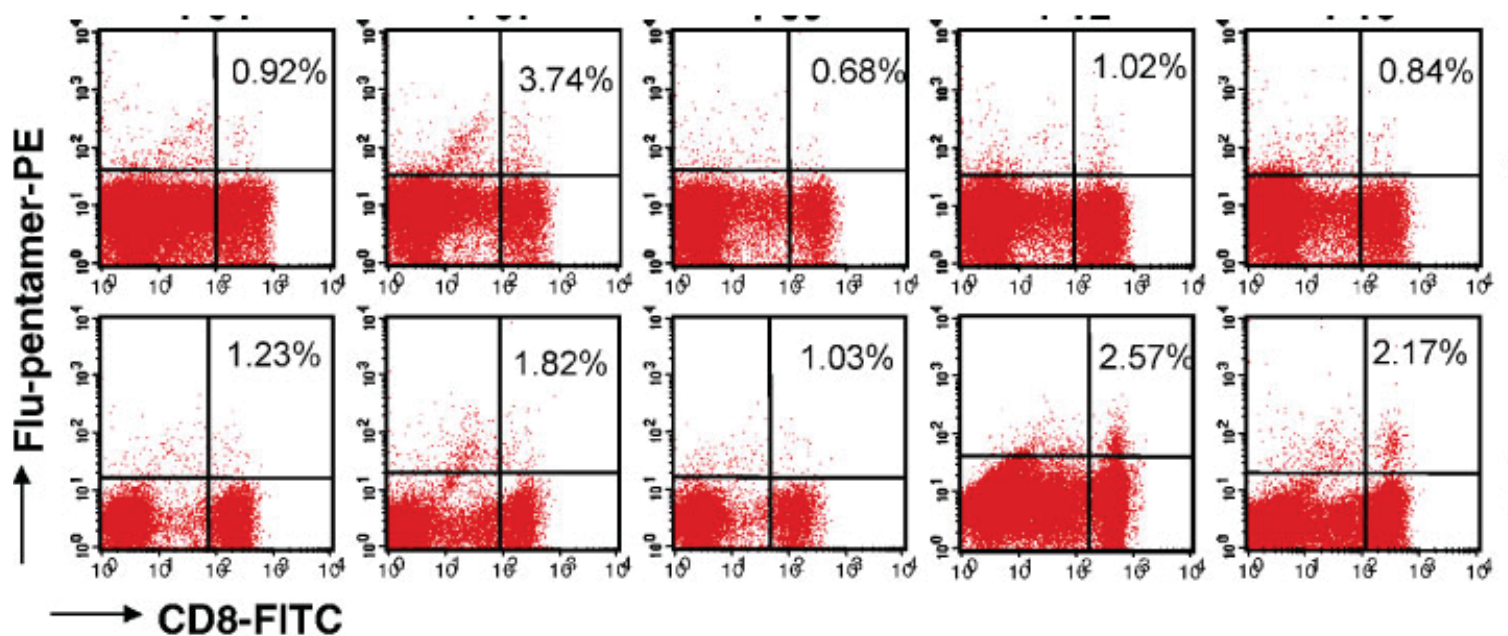

\section{ex vivo}

After in vitro restimulation

\section{B. PSCA}
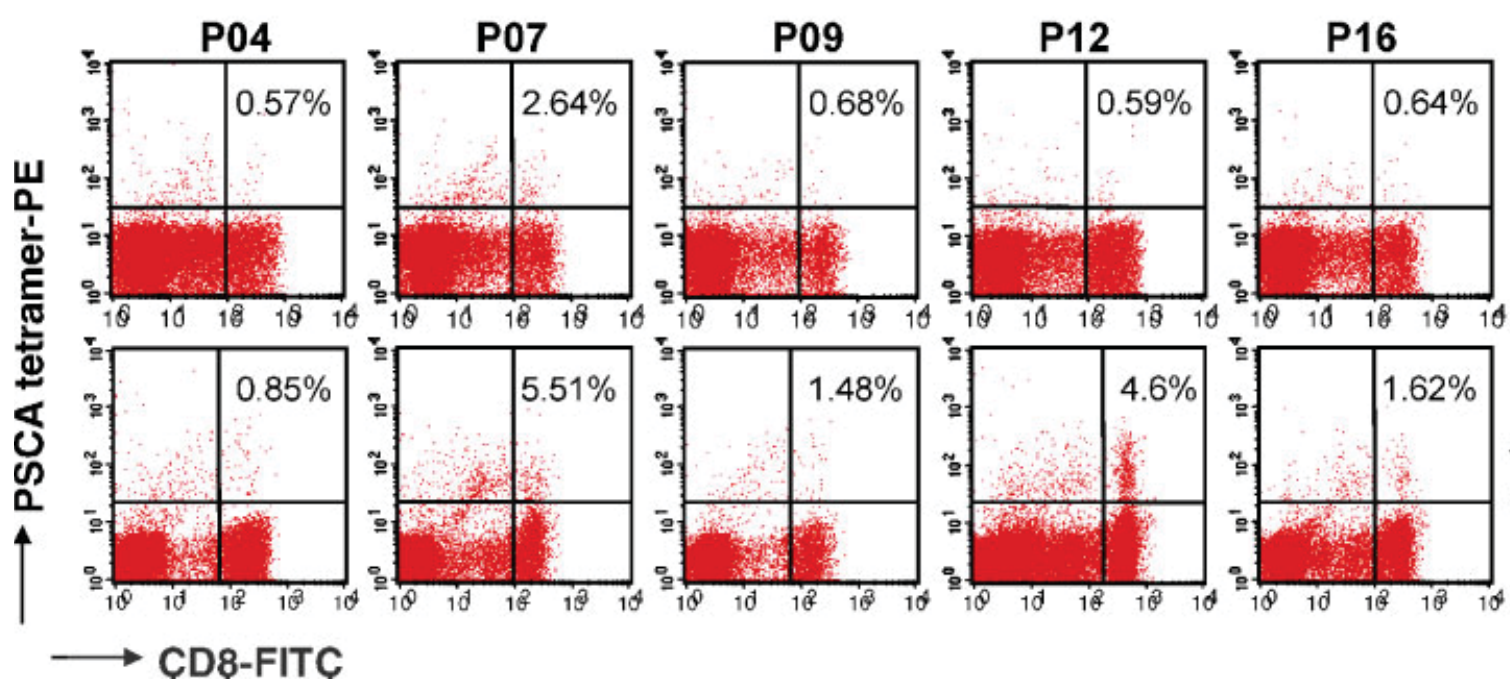

\section{ex vivo}
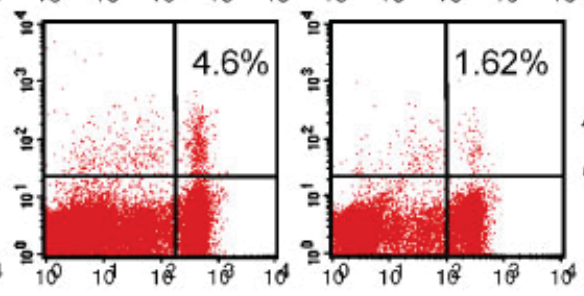

After in vitro restimulation

Fig. 5. Determination of antigen-specific CD8 ${ }^{+}$T-cells in $\mathrm{CaP}$ patients and the specific CTL stimulation capacity of autologous MoDCs. Percentage of FluM 58-66 $_{\text {(panel A) and PSCA }}$ (4-22 $_{\text {(panel B) specific CD8 }}{ }^{+}$T-cells in PBMC of five HLA-A*020l positive CaP patients was determined by MHC class I peptide-multimer staining, either using ex vivo PBMC without restimulation (upper panels), or cells after one cycle of in vitro restimulation with autologous matured MoDCs pulsed with the relevant peptides (bottom panels). Numbers given in each dot plot denote the percentage of peptide-specific CD8 ${ }^{+} \mathrm{T}$-cells of the total $\mathrm{CD} 8^{+}$lymphocyte populations. The data represent one of three independent experiments which all showed similar results. [Color figure can be viewed in the online issue, which is available at www.interscience. wiley.com.]

shown activation of $\mathrm{CD}^{+}{ }^{+} \mathrm{T}$-cells in patients with metastatic melanoma [21].

In conclusion, the immune system of patients with androgen-independent $\mathrm{CaP}$ seems not to be impaired, at least not in the context of the cellular functions tested in this study. The ability to produce DCs with robust stimulatory and migratory capacities will underpin future efforts to induce beneficial T-cell immunity in $\mathrm{CaP}$ patients using DC-based cellular vaccination approaches.

\section{ACKNOWLEDGMENTS}

We thank C. Böhme and R. Steingruber for clinical assistance and Dr. W. Seelentag and the whole Physics team at Clinics of Radio-Oncology for irradiating DCs. We thank Dr. M. Fopp and Dr. J. Hering and the personel from the regional blood donation center SRC, St. Gallen. We also thank Prof. Dr. R. Förster (Institute of Immunology, Hannover Medical School, Germany) for providing CCR7 antibody. The assistance of Dr. B. 
Cameron (Avidex Ltd.) in the production of HLA-A2 tetramers is gratefully acknowledged.

\section{REFERENCES}

1. Schuler G, Schuler-Thurner B, Steinman RM. The use of dendritic cells in cancer immunotherapy. Curr Opin Immunol 2003;15(2):138-147.

2. Banchereau J, Steinman RM. Dendritic cells and the control of immunity. Nature 1998;392(6673):245-252.

3. Dhodapkar MV, Steinman RM, Krasovsky J, Munz C, Bhardwaj N. Antigen-specific inhibition of effector $\mathrm{T}$ cell function in humans after injection of immature dendritic cells. J Exp Med 2001;193(2):233-238.

4. Jung S, Unutmaz D, Wong P, Sano G, De los Santos K, Sparwasser T, Wu S, Vuthoori S, Ko K, Zavala F, Pamer EG, Littman DR, Lang RA. In vivo depletion of CD11c(+) dendritic cells abrogates priming of CD8(+) T cells by exogenous cellassociated antigens. Immunity 2002;17(2):211-220.

5. Ludewig B, Oehen S, Barchiesi F, Schwendener RA, Hengartner $\mathrm{H}$, Zinkernagel RM. Protective antiviral cytotoxic T cell memory is most efficiently maintained by restimulation via dendritic cells. J Immunol 1999;163(4):1839-1844.

6. Romani N, Gruner S, Brang D, Kampgen E, Lenz A, Trockenbacher B, Konwalinka G, Fritsch PO, Steinman RM, Schuler G. Proliferating dendritic cell progenitors in human blood. J Exp Med 1994;180(1):83-93.

7. Sallusto F, Lanzavecchia A. Efficient presentation of soluble antigen by cultured human dendritic cells is maintained by granulocyte/macrophage colony-stimulating factor plus interleukin 4 and downregulated by tumor necrosis factor alpha. J Exp Med 1994;179(4):1109-1118.

8. Scandella E, Men Y, Gillessen S, Forster R, Groettrup M. Prostaglandin E2 is a key factor for CCR7 surface expression and migration of monocyte-derived dendritic cells. Blood 2002; 100(4):1354-1361.

9. Scandella E, Men Y, Legler DF, Gillessen S, Prikler L, Ludewig B, Groettrup M. CCL19/CCL21-triggered signal transduction and migration of dendritic cells requires prostaglandin E2. Blood 2004;103(5):1595-1601.

10. Tjoa B, Erickson S, Barren R, 3rd, Ragde H, Kenny G, Boynton A, Murphy G. In vitro propagated dendritic cells from prostate cancer patients as a component of prostate cancer immunotherapy. Prostate 1995;27(2):63-69.

11. Murphy GP, Tjoa BA, Simmons SJ, Ragde H, Rogers M, Elgamal A, Kenny GM, Troychak MJ, Salgaller ML, Boynton AL. Phase II prostate cancer vaccine trial: Report of a study involving 37 patients with disease recurrence following primary treatment. Prostate 1999;39(1):54-59.
12. Heiser A, Coleman D, Dannull J, Yancey D, Maurice MA, Lallas CD, Dahm P, Niedzwiecki D, Gilboa E, Vieweg J. Autologous dendritic cells transfected with prostate-specific antigen RNA stimulate CTL responses against metastatic prostate tumors. J Clin Invest 2002;109(3):409-417.

13. Barrou B, Benoit G, Ouldkaci M, Cussenot O, Salcedo M, Agrawal S, Massicard S, Bercovici N, Ericson ML, Thiounn N. Vaccination of prostatectomized prostate cancer patients in biochemical relapse, with autologous dendritic cells pulsed with recombinant human PSA. Cancer Immunol Immunother 2004; 53(5):453-460.

14. Fong L, Brockstedt D, Benike C, Breen JK, Strang G, Ruegg CL, Engleman EG. Dendritic cell-based xenoantigen vaccination for prostate cancer immunotherapy. J Immunol 2001;167(12):71507156.

15. Forster R, Schubel A, Breitfeld D, Kremmer E, Renner-Muller I, Wolf E, Lipp M. CCR7 coordinates the primary immune response by establishing functional microenvironments in secondary lymphoid organs. Cell 1999;99(1):23-33.

16. Steinman RM, Nussenzweig MC. Avoiding horror autotoxicus: The importance of dendritic cells in peripheral $\mathrm{T}$ cell tolerance. Proc Natl Acad Sci USA 2002;99(1):351-358.

17. Jonuleit H, Kuhn U, Muller G, Steinbrink K, Paragnik L, Schmitt E, Knop J, Enk AH. Pro-inflammatory cytokines and prostaglandins induce maturation of potent immunostimulatory dendritic cells under fetal calf serum-free conditions. Eur J Immunol 1997;27(12):3135-3142.

18. Luft T, Jefford M, Luetjens P, Toy T, Hochrein H, Masterman KA, Maliszewski C, Shortman K, Cebon J, Maraskovsky E. Functionally distinct dendritic cell (DC) populations induced by physiologic stimuli: Prostaglandin E(2) regulates the migratory capacity of specific DC subsets. Blood 2002;100(4):13621372.

19. De Vries IJ, Krooshoop DJ, Scharenborg NM, Lesterhuis WJ, Diepstra JH, Van Muijen GN, Strijk SP, Ruers TJ, Boerman OC, Oyen WJ, Adema GJ, Punt CJ, Figdor CG. Effective migration of antigen-pulsed dendritic cells to lymph nodes in melanoma patients is determined by their maturation state. Cancer Res 2003;63(1):12-17.

20. Toes RE, Ossendorp F, Offringa R, Melief CJ. CD4 T cells and their role in antitumor immune responses. J Exp Med 1999; 189(5):753-756.

21. Schuler-Thurner B, Schultz ES, Berger TG, Weinlich G, Ebner S, Woerl P, Bender A, Feuerstein B, Fritsch PO, Romani N, Schuler G. Rapid induction of tumor-specific type $1 \mathrm{~T}$ helper cells in metastatic melanoma patients by vaccination with mature, cryopreserved, peptide-loaded monocyte-derived dendritic cells. J Exp Med 2002;195(10): 1279-1288. 